\title{
Changes in neurokinin A airway responsiveness with inhaled lysine-acetylsalicylate in asthma
}

\author{
N. Crimi, R. Polosa, G. Prosperini, S. Magrì, I. Ciamarra, A. Mistretta
}

Changes in neurokinin A airway responsiveness with inhaled lysine-acetylsalicylate in asthma. N. Crimi, R. Polosa, G. Prosperini, S. Magrì, I. Ciamarra, A. Mistretta. @ERS Journals Ltd 1996.

ABSTRACT: Endogenously released cyclooxygenase products modulate the bronchoconstrictor response to various stimuli in asthma. Little is known of the change in airway responsiveness to neurokinin A (NKA) after cyclooxygenase blockade. In this randomized, double-blind, placebo-controlled study, we have investigated the effect of the potent cyclooxygenase inhibitor, lysine acetylsalicylate (L-ASA) administered by inhalation, on the bronchoconstrictor response both to neurokinin $A$ (NKA) and methacholine in nine asthmatic subjects.

Subjects attended the laboratory on four separate occasions to receive nebulized L-ASA (solution of $90 \mathrm{mg} \cdot \mathrm{mL}^{-1}$ ) or matched placebo (glycine, solution of $30 \mathrm{mg} \cdot \mathrm{mL}^{-1}$ ) 15 min prior to bronchial challenge with NKA or methacholine, in a randomized, double-blind order. Changes in airway calibre were followed as forced expiratory volume in one second (FEV1) and agonist responsiveness, expressed as the provocative concentration causing a $20 \%$ fall in $\mathrm{FEV} 1$ from baseline (PC20).

L-ASA elicited a significant fall in FEV1 from baseline. When compared with placebo, inhaled L-ASA reduced the airway responsiveness to NKA in 8 of the 9 subjects studied, the geometric mean (range) values for PC20 NKA increasing significantly from $153.2(52.0-258.9)$ to $303.1(83.4-668.5) \mu \mathrm{g} \cdot \mathrm{mL}^{-1}$ after placebo and L-ASA, respectively. However, no significant change in airway responsiveness to methacholine was recorded after L-ASA, their geometric mean (range) PC20 values being $1.60(0.17-9.59)$ and $1.53(0.09-14.01) \mathrm{mg} \cdot \mathrm{mL}^{-1}$ after placebo and L-ASA, respectively.

The small decrease in airway responsiveness to neurokinin A after administration of lysine acetylsalicylate by inhalation suggests that endogenous prostaglandins may play a contributory protective role in the airway response to neurokinin $A$ in human asthma.

Eur Respir J., 1996, 9, 1139-1145.
Istituto Malattie Apparato Respiratorio, Università di Catania, Catania, Italy.

Correspondence: N. Crimi

Istituto Malattie Apparato Respiratorio

Università di Catania

Via Passo Gravina, 187

95125 Catania

Italy

\section{Keywords: Asthma}

bronchoconstriction

lysine-acetylsalicylate

neurokinin A

Received: July 271995

Accepted after revision December 281995
Sensory neuropeptides, such as substance P (SP) and neurokinin A (NKA), exhibit a range of features which may be relevant to the pathophysiology of asthma, including contraction of airway smooth muscle, increased vascular permeability, mucus secretion and activation of cholinergic neurotransmission [1]. Immunocytochemical studies have demonstrated the presence of sensory neuropeptides and their receptors within the upper and lower airways both in man and rodents [2-4]. Although compared with rodents the nerve fibres containing sensory neuropeptides are less dense in human airway tissue, recent studies on necroscopic tissue, bronchoalveolar lavage fluid, and induced sputum have shown increased amounts of SP in the airways of asthmatics compared to controls [5-7]. Different authors have demonstrated that both SP and NKA produce dose-related bronchoconstriction when administered by inhalation to asthmatic subjects, NKA being more potent than SP and asthmatic subjects being more responsive than normal subjects [8-12].

The mode of action by which sensory neuropeptides elicit bronchoconstriction in asthma is not well understood. The bronchoconstrictor effect of nebulized NKA in asthmatic patients is inhibited by prior treatment with nedocromil sodium $[10,13]$, suggesting that this response may be evoked indirectly rather than through direct stimulation of airway smooth muscle. There is some support for an action of sensory neuropeptides in eliciting prostaglandin synthesis. Recent in vitro studies support the view that many of the biological responses of the sensory neuropeptides may result from the local release of bioactive prostanoids [14-16].

In line with the notion that administration of bronchoactive drugs by inhalation achieves maximum effect with smaller doses, BIANCO and co-workers $[17,18]$ have recently shown that the potent cyclooxygenase inhibitor, aspirin administered as an aerosol of lysine acetylsalicylate (L-ASA) solution elicits better protection against nonspecific stimuli in the airways of asthmatics than when given orally. Using this alternative experimental approach, we intend to expand our previous observations with other nonspecific agonists $[19,20]$, by evaluating the relative contribution of contractile prostaglandins to the airway response provoked by inhaled NKA in asthmatic subjects. 
We have, therefore, investigated the effect of prior administration of L-ASA, given by inhalation, on the airways response of asthmatic subjects both to NKA and to methacholine. Methacholine was included in the present study to evaluate the specificity of inhaled L-ASA in the response.

\section{Methods}

\section{Subjects}

Nine asthmatic subjects ( 5 females and 4 males), with a mean $( \pm$ SEM) age of $35( \pm 4)$ yrs, referred to our chest clinic with stable asthma, participated in the study (table 1). They were nonsmokers and all except two were atopic as defined by positive skin-prick tests $(>2 \mathrm{~mm}$ weal response) to one or more of six common aeroallergens (Dermatophagoides pteronyssinus, Dermatophagoides farinae, wall pellitory grass, mixed grass pollens, cat fur, dog hair). At the beginning of the study, all subjects were asymptomatic, with a baseline forced expiratory volume in one second $\left(\mathrm{FEV}_{1}\right)$ of $>70 \%$ of their predicted values. None had received oral corticosteroids, theophylline, antihistamines or sodium cromoglycate within the preceding 4 weeks. Inhaled bronchodilators were discontinued for at least $8 \mathrm{~h}$ prior to each visit to the laboratory, although subjects were allowed to continue inhaled corticosteroids as usual. On close questioning, none of the subjects studied had a positive history of aspirin intolerance. Subjects were not studied within 4 weeks of an upper respiratory tract infection or exacerbation of their asthma, and all visits to the laboratory were carried out at the same time of day and outside the pollen season. The study was approved by the Ethics Subcommittee of the Department of Respiratory Diseases (University of Catania), and all subjects gave their informed consent.

\section{Bronchial provocation}

Airway calibre was recorded before and during the provocation as FEV1, using a dry wedge spirometer (Vitalograph, Buckinghamshire, UK), the better of two consecutive measurements being used for analysis.

Methacholine (Sigma Chemical Co., St Louis, MO, USA) and NKA (Peninsula Laboratories Ltd) were made up in phosphate-buffered saline (PBS) and $0.9 \%$ sodium chloride (1\% albumin solution), respectively, to produce a range of increasing doubling concentrations of 0.03-64.00 $\mathrm{mg} \cdot \mathrm{mL}^{-1}$ and $3.9-500 \mu \mathrm{g} \cdot \mathrm{mL}^{-1}$. The aqueous solutions were administered as aerosols, generated from a starting volume of $3 \mathrm{~mL}$, in a disposable Inspiron Mini-nebulizer (C.R. Bard International, Sunderland, UK) driven by compressed air at $8 \mathrm{~L} \cdot \mathrm{min}^{-1}$. Under these conditions, the nebulizer had an output of $0.48 \mathrm{~mL} \cdot \mathrm{min}^{-1}$ and generated an aerosol with a mass median particle diameter of $4.7 \mu \mathrm{m}$ [21]. Wearing a noseclip, subjects inhaled the aerosolized solutions in five breaths from end-tidal volume to full inspiratory capacity via a mouthpiece, as described by Chai et al. [22]. Subjects were trained to take $3 \mathrm{~s}$ to reach full inspiratory capacity.

\section{Study design}

The study consisted of two distinct phases

Phase 1. Subjects attended the laboratory on two separate occasions, at least $72 \mathrm{~h}$ apart, to undertake concentration-response studies with inhaled methacholine and NKA in the absence of any drug treatment. On the first occasion, after $15 \mathrm{~min}$ rest, three baseline measurements of FEV1 were made at intervals of 3 min followed by inhalation of $0.9 \%$ sodium chloride and further FEV1 measurements repeated at 1 and 3 min. Provided FEV1 had not fallen by $>10 \%$ of the baseline value, a methacholine concentration-response study was carried out. After administration of each methacholine concentration, FEV1 was measured at 1 and $3 \mathrm{~min}$. Increasing doubling concentrations of methacholine were inhaled at 5 min intervals until FEV1 had fallen by $>20 \%$ of the postsaline baseline value. The fall in FEV1 following each concentration of agonist was expressed as a percentage of the higher of the two postsaline baseline FEV1 recordings. The percentage fall in FEV1 was plotted against the cumulative concentration of agonist on a logarithmic scale, and the provocative concentration required to produce a $20 \%$ decrease in FEV1 from the post-saline baseline value (PC20) was determined by linear interpolation. On the second occasion, a bronchial provocation test with inhaled NKA was undertaken in a similar manner to that described for methacholine. FEV1 measurements were

Table 1. - Demographic details of subjects studied

\begin{tabular}{|c|c|c|c|c|c|c|}
\hline $\begin{array}{l}\text { Subject } \\
\text { No. }\end{array}$ & Sex & $\begin{array}{l}\text { Age } \\
\text { yrs }\end{array}$ & $\begin{array}{c}\text { Baseline FEV1 } \\
\% \text { pred }\end{array}$ & Atopy§ & $\begin{array}{l}\mathrm{PC} 20 \text { meth } \\
\mathrm{mg} \cdot \mathrm{mL}^{-1}\end{array}$ & $\begin{array}{c}\mathrm{PC} 20 \mathrm{NKA}^{\mathrm{N}} \\
\mu \mathrm{g} \cdot \mathrm{mL}^{-1}\end{array}$ \\
\hline 1 & $\mathrm{~F}$ & 39 & 91 & W & 1.70 & 156.2 \\
\hline 2 & $\mathrm{~F}$ & 40 & 88 & W & 1.69 & 174.1 \\
\hline 3 & F & 29 & 79 & W & 0.33 & 80.6 \\
\hline 4 & M & 21 & 100 & W-D & 6.48 & 122.1 \\
\hline 5 & $\mathrm{~F}$ & 55 & 82 & - & 11.90 & 320.3 \\
\hline 6 & F & 25 & 79 & W & 0.98 & 191.1 \\
\hline 7 & M & 42 & 105 & - & 3.47 & 174.2 \\
\hline 8 & M & 38 & 92 & W-D & 0.11 & 148.5 \\
\hline 9 & M & 22 & 72 & $\mathrm{D}$ & 1.59 & 96.6 \\
\hline Mean & & 35 & 87 & & $1.52^{\#}$ & $151.0^{\#}$ \\
\hline SEM & & \pm 4 & \pm 4 & & $(0.11-11.9)$ & (80.6-320.3) \\
\hline
\end{tabular}

\#: geometric mean (range); §: atopic, positive immediate skin test to one or more allergens. D: Dermatophagoides; W: wall pellitory grass; FEV1: forced expiratory volume in one second; PC20: provocation concentration producing a 20\% fall in FEV1; meth: methacholine; NKA: neurokinin A; F: female; M: male. 
recorded 1 and 3 min after inhalation of each concentration of NKA and the corresponding PC20 FEV1 values derived.

Phase 2. Subjects attended the laboratory on four separate occasions, at least 4 days apart, to undertake concentration-response studies with methacholine and NKA after receiving nebulized L-ASA (Lirca Synthelabo, Limito, Milano, Italy) or matched nebulized vehicle placebo, administered double-blind and in random order $15 \mathrm{~min}$ prior to challenge. Both the active and placebo solutions were freshly prepared by an independent investigator on the basis of a randomized code and then returned to the conducting physician to administer to the attending subject. On each occasion, after 15 min rest, three baseline measurements of FEV1 were made at intervals of $3 \mathrm{~min}$ followed by inhalation of nebulized L-ASA $\left(90 \mathrm{mg} \cdot \mathrm{mL}^{-1}\right.$, $4 \mathrm{~mL}$; $525 \mathrm{mOsm} \cdot \mathrm{L}^{-1}$, $\mathrm{pH} 5.25$; a $90 \mathrm{mg} \cdot \mathrm{mL}^{-1}$ solution of L-ASA actually contains $50 \mathrm{mg}$ of ASA $\cdot \mathrm{mL}^{-1}$ ) or nebulized vehicle placebo consisting of a solution of glycine (30 mg $\cdot \mathrm{mL}^{-1}, 4 \mathrm{~mL} ; 605 \mathrm{mOsm} \cdot \mathrm{L}^{-1}, \mathrm{pH} 5.90$ ) in $0.9 \%$ sodium chloride adjusted to the same $\mathrm{pH}$ and tonicity as the L-ASA. The aerosol solutions were generated from a starting volume of $4 \mathrm{~mL}$ in an Inspiron mini-nebulizer driven by compressed air at $6 \mathrm{~L} \cdot \mathrm{min}^{-1}$, and inhaled to dryness by deep tidal breathing over a 7-9 min time period. The same nebulizer was used for all studies on all subjects. Further FEV1 measurements were repeated at 1, 5, 10 and $15 \mathrm{~min}$ after drug/placebo inhalation and dose-response studies with increasing concentrations of methacholine and NKA carried out in a similar manner to that described in Phase 1.

\section{Data analyses}

Results are expressed as the mean \pm SEM unless otherwise stated and $\mathrm{p}<0.05$ was accepted as the minimum level of statistical significance. Pre- and post-treatment baseline values of $\mathrm{FEV} 1$ prior to bronchial challenge were compared between and within study days by two-factor analysis of variance (ANOVA) followed by NeumanKeuls test where appropriate.

The repeatability of the NKA challenge procedure was determined according to the method described by ALTMAN and BLAND [23] of plotting the difference against the mean of the logarithmically transformed $\mathrm{PC} 20$ values obtained on the placebo and open study days. The mean and standard deviation (SD) of the difference between these values were then derived and used to calculate the coefficient of repeatability (CoR) between the results of the two study days.

Values of PC20 methacholine, and NKA following treatment with L-ASA and placebo were logarithmically transformed to normalize their distribution and compared by the Student's t-test for paired data.

Any relationship between the airway responses to methacholine and NKA was examined by least-squares linear regression analysis of their logarithmically transformed PC20 values. Least-squares linear regression analysis was also used to evaluate: 1) any relationship between the concentration ratio after the drug and the airway responses to methacholine and NKA; and 2) any relationship between the magnitude of fall in FEV1 after exposure to L-ASA and baseline airway responsiveness to methacholine and NKA.

Table 2. - Effect of pretreatment with inhaled L-ASA and placebo on baseline FEV 1 values in NKA and methacholine study days

\begin{tabular}{|c|c|c|c|c|c|c|c|c|c|c|}
\hline \multirow{2}{*}{$\begin{array}{l}\text { Subject } \\
\text { No. }\end{array}$} & \multirow{2}{*}{$\begin{array}{l}\text { Pre-p } \\
\text { FEV1 }\end{array}$} & \multicolumn{4}{|c|}{ Post-placebo FEV1 L } & \multicolumn{2}{|l|}{ Pre-L-ASA } & \multicolumn{2}{|c|}{ Post-L-ASA FEV1 L } & \multirow[b]{2}{*}{$15 \mathrm{~min}$} \\
\hline & & $1 \mathrm{~min}$ & $5 \mathrm{~min}$ & $10 \mathrm{~min}$ & $15 \min$ & FEV1 L & $1 \mathrm{~min}$ & $5 \mathrm{~min}$ & $10 \mathrm{~min}$ & \\
\hline \multicolumn{11}{|c|}{ NKA study days } \\
\hline 1 & 2.55 & 2.43 & 2.50 & 2.45 & 2.44 & 2.49 & 2.07 & 2.21 & 2.19 & 2.35 \\
\hline 2 & 2.36 & 2.18 & 2.34 & 2.29 & 2.31 & 2.38 & 2.11 & 2.18 & 1.99 & 2.22 \\
\hline 3 & 2.21 & 2.10 & 2.08 & 2.11 & 2.24 & 2.46 & 1.76 & 1.88 & 2.00 & 2.25 \\
\hline 4 & 4.15 & 3.94 & 3.79 & 3.98 & 4.07 & 3.79 & 3.49 & 3.46 & 3.64 & 3.71 \\
\hline 5 & 1.85 & 1.44 & 1.34 & 1.73 & 1.75 & 1.88 & 1.43 & 1.40 & 1.57 & 1.50 \\
\hline 6 & 2.53 & 2.15 & 2.36 & 2.33 & 2.35 & 2.27 & 1.62 & 1.72 & 1.83 & 1.92 \\
\hline 7 & 3.77 & 3.52 & 3.59 & 3.63 & 3.70 & 3.64 & 3.28 & 3.46 & 3.46 & 3.45 \\
\hline 8 & 2.89 & 2.59 & 2.72 & 2.77 & 2.82 & 2.76 & 2.62 & 2.52 & 2.57 & 2.62 \\
\hline 9 & 2.98 & 2.57 & 2.56 & 2.47 & 2.72 & 2.76 & 2.48 & 2.40 & 2.43 & 2.74 \\
\hline Mean & 2.81 & 2.55 & 2.59 & 2.64 & 2.71 & 2.71 & 2.32 & 2.36 & 2.41 & 2.53 \\
\hline \pm SEM & \pm 0.25 & \pm 0.25 & \pm 0.23 & \pm 0.24 & \pm 0.25 & \pm 0.21 & \pm 0.24 & \pm 0.23 & \pm 0.24 & \pm 0.23 \\
\hline \multicolumn{11}{|c|}{ Methacholine study days } \\
\hline 1 & 2.59 & 2.40 & 2.51 & 2.49 & 2.48 & 2.51 & 2.16 & 2.19 & 2.21 & 2.33 \\
\hline 2 & 1.98 & 1.94 & 2.00 & 2.09 & 2.11 & 2.08 & 1.62 & 1.70 & 1.83 & 1.95 \\
\hline 3 & 2.50 & 2.17 & 2.23 & 2.38 & 2.46 & 2.40 & 2.08 & 2.00 & 2.12 & 2.32 \\
\hline 4 & 4.22 & 3.98 & 4.06 & 4.02 & 4.06 & 4.12 & 3.70 & 3.90 & 3.87 & 3.99 \\
\hline 5 & 1.80 & 1.58 & 1.69 & 1.82 & 1.83 & 1.78 & 1.25 & 1.30 & 1.35 & 1.55 \\
\hline 6 & 2.25 & 1.47 & 1.66 & 1.53 & 1.98 & 2.31 & 1.83 & 1.79 & 1.80 & 2.01 \\
\hline 7 & 3.65 & 3.28 & 3.31 & 3.51 & 3.54 & 3.50 & 3.10 & 3.23 & 3.30 & 3.41 \\
\hline 8 & 3.20 & 2.88 & 2.86 & 2.83 & 2.95 & 3.09 & 3.00 & 2.93 & 2.90 & 3.05 \\
\hline 9 & 3.32 & 3.06 & 2.95 & 3.06 & 3.17 & 3.13 & 2.72 & 2.93 & 2.89 & 3.10 \\
\hline Mean & 2.83 & 2.53 & 2.59 & 2.64 & 2.73 & 2.77 & 2.38 & 2.44 & 2.47 & 2.63 \\
\hline \pm SEM & \pm 0.27 & \pm 0.28 & \pm 0.27 & \pm 0.27 & \pm 0.25 & \pm 0.25 & \pm 0.26 & \pm 0.28 & \pm 0.27 & \pm 0.27 \\
\hline
\end{tabular}

L-ASA: lysine acetylsalicylate; FEV1: forced expiratory volume in one second; NKA: neurokinin A; pre-p: pre-placebo. 


\section{Results}

\section{Effect of inhaled L-ASA on airway calibre}

There was no significant difference in mean ( \pm SEM) baseline values of FEV1 between any of the study days, with values ranging from $2.71 \pm 0.21$ to $2.83 \pm 0.27 \mathrm{~L}$ (table 2 ). Both inhaled placebo (glycine solution) and L-ASA caused an immediate fall in FEV 1 from baseline. FEV1 values obtained after L-ASA, were significantly lower than predrug FEV1 baseline values, with a peak effect at 1 min, the mean ( \pm SEM) FEV1 values decreasing $15.8 \%$ from $2.71 \pm 0.21$ to $2.32 \pm 0.24 \mathrm{~L}(\mathrm{p}<0.01)$ and $15.3 \%$ from $2.77 \pm 0.25$ to $2.38 \pm 0.26 \mathrm{~L}(\mathrm{p}<0.01)$ on the NKA and methacholine study days, respectively, (table 2).

Although $15 \mathrm{~min}$ after nebulized L-ASA, FEV1 values were still $7.7 \%$ and $5.6 \%$ lower than their predrug FEV1 baseline values on the NKA and methacholine study days, respectively (table $2 \mathrm{a}$ and $\mathrm{b}$ ), these values were significantly higher compared to the values measured at the 1 min time-point. Mean values of FEV1 post L-ASA were significantly lower than those postplacebo, and this was consistent at 5, 10 and $15 \mathrm{~min}$ time-points. No significant correlations could be established between the magnitude of fall in FEV1 after the active drug (at all the time-points studied) and baseline airway responsiveness to NKA or methacholine.

\section{Effect of inhaled L-ASA on concentration-response curve to NKA and methacholine}

The challenge procedure with NKA in this group of subjects was found to be repeatable, with a coefficient which was within 1.5 doubling dilutions (for 7 of the 9 subjects to within a single doubling dilution). These findings were consistent with the repeatability data previously obtained in our laboratory with bronchial provocation tests with NKA [10, 24].

In phase 1, inhaled methacholine and NKA produced concentration-related falls in FEV1. The geometric mean (range) of PC20 values obtained were 1.52 (0.11-11.90) $\mathrm{mg} \cdot \mathrm{mL}^{-1}$ and $151.0(80.6-320.3) \mu \mathrm{g} \cdot \mathrm{mL}^{-1}$ for methacholine

Table 3. - Effects of pretreatment with inhaled L-ASA and placebo on airway NKA and methacholine responsiveness

\begin{tabular}{lcccc}
\hline $\begin{array}{l}\text { Subj. } \\
\text { No. }\end{array}$ & $\begin{array}{c}\text { PC20 NKA } \\
\text { Placebo }\end{array}$ & $\begin{array}{r}\mu \cdot \mathrm{mL}^{-1} \\
\text { L-ASA }\end{array}$ & $\begin{array}{c}\text { PC20 METH } \\
\text { Placebo }\end{array}$ & $\begin{array}{c}\mathrm{mg} \cdot \mathrm{mL}^{-1} \\
\mathrm{~L}-\mathrm{ASA}\end{array}$ \\
\hline 1 & 118.0 & 241.1 & 1.83 & 1.77 \\
2 & 199.1 & 668.5 & 1.81 & 1.68 \\
3 & 99.1 & 230.9 & 0.40 & 0.42 \\
4 & 250.8 & 390.6 & 6.27 & 5.69 \\
5 & 258.9 & 545.0 & 9.59 & 14.01 \\
6 & 150.2 & 83.4 & 0.88 & 1.06 \\
7 & 209.4 & 421.6 & 3.30 & 3.00 \\
8 & 52.0 & 277.8 & 0.17 & 0.09 \\
9 & 187.7 & 280.1 & 1.71 & 1.58 \\
\hline G. mean & 153.2 & 303.1 & 1.60 & 1.53 \\
(range) & $(52.0-$ & $(83.4-$ & $(0.17-$ & $(0.09-$ \\
& $258.9)$ & $668.5)$ & $9.59)$ & $14.01)$ \\
\hline
\end{tabular}

Subj: subjects. G. mean: geometric mean. For further abbreviations see legend to tables 1 and 2 . and NKA respectively (table 1 ). No significant correlation was observed between $\mathrm{PC} 20$ values for methacholine and NKA.

In phase 2, when compared to placebo, inhaled L-ASA had a significant protective effect against the fall in FEV1 produced by NKA. L-ASA produced a displacement of the NKA concentration-response curve to the right in 8 out of the 9 subjects studied (fig. 1 and table 3). For these subjects, the geometric mean (range) PC20 NKA values increased twofold from $153.2(52.0-258.9)$ to 303.1 (83.4-668.5) $\mu \mathrm{g} \cdot \mathrm{mL}^{-1}$ after placebo and L-ASA respectively $(\mathrm{p}<0.01)$ (table 3$)$. No correlation could be found between baseline airway reactivity and the protection of airway response to NKA after L-ASA exposure.

Inhaled L-ASA, despite being effective in inducing significant changes in baseline airway calibre, failed to alter the airway response to methacholine (fig. 2, table 3 ). The geometric mean (range) PC20 methacholine value of $1.60(0.17-9.59) \mathrm{mg} \cdot \mathrm{mL}^{-1}$ after placebo not being significantly different from that of $1.53(0.09-14.01) \mathrm{mg} \cdot \mathrm{mL}^{-1}$ obtained after L-ASA (table 3).

\section{Discussion}

In asthmatic subjects, L-ASA administered by inhalation elicits a small but significant protection of the airways against NKA-induced bronchoconstriction. The protection afforded by L-ASA occurred in eight of the nine subjects studied and amounted to an approximately twofold displacement of the concentration-response curves to the right, which is similar to that reported with other agonists [17-20]. In addition, following L-ASA exposure, we have failed to show a significant change in airway responsiveness to methacholine.

Inhaled L-ASA was chosen as a cyclooxygenase inhibitor because of its demonstrated potency and specificity. The dosage of inhaled L-ASA used in the present study and the timing of administration before bronchial challenge were chosen on the basis of previous studies which have been shown to effectively reduce the bronchospastic response to fog, adenosine and histamine in asthmatic subjects [17-20].

We have demonstrated that inhaled aspirin inhibits the airway response to NKA by approximately twofold. It is likely, as also supported by the findings of BIANCO and co-workers $[17,18]$ in their recent work with fog-induced bronchoconstriction, that the route of administration may have maximized the degree of protection against the airway response to NKA.

The mechanism by which cyclooxygenase blockade attenuates the bronchoconstrictor response to NKA requires some speculation. We have shown no bronchodilator effect with inhaled L-ASA but, rather, we have confirmed the occurrence of some bronchoconstriction after inhaled L-ASA $[19,20]$. Although this may be due, in part, to an irritant effect of the drug, we cannot exclude other possibilities, since comparison with changes in FEV1 obtained after a placebo (glycine solution) matched for osmolality and $\mathrm{pH}$ showed a significant difference. The reason for this is not known but differences in subjects' characteristics is a possibility. Most of the asthmatic subjects studied in the present investigation had their bronchial reactivity in the severe-moderate range 

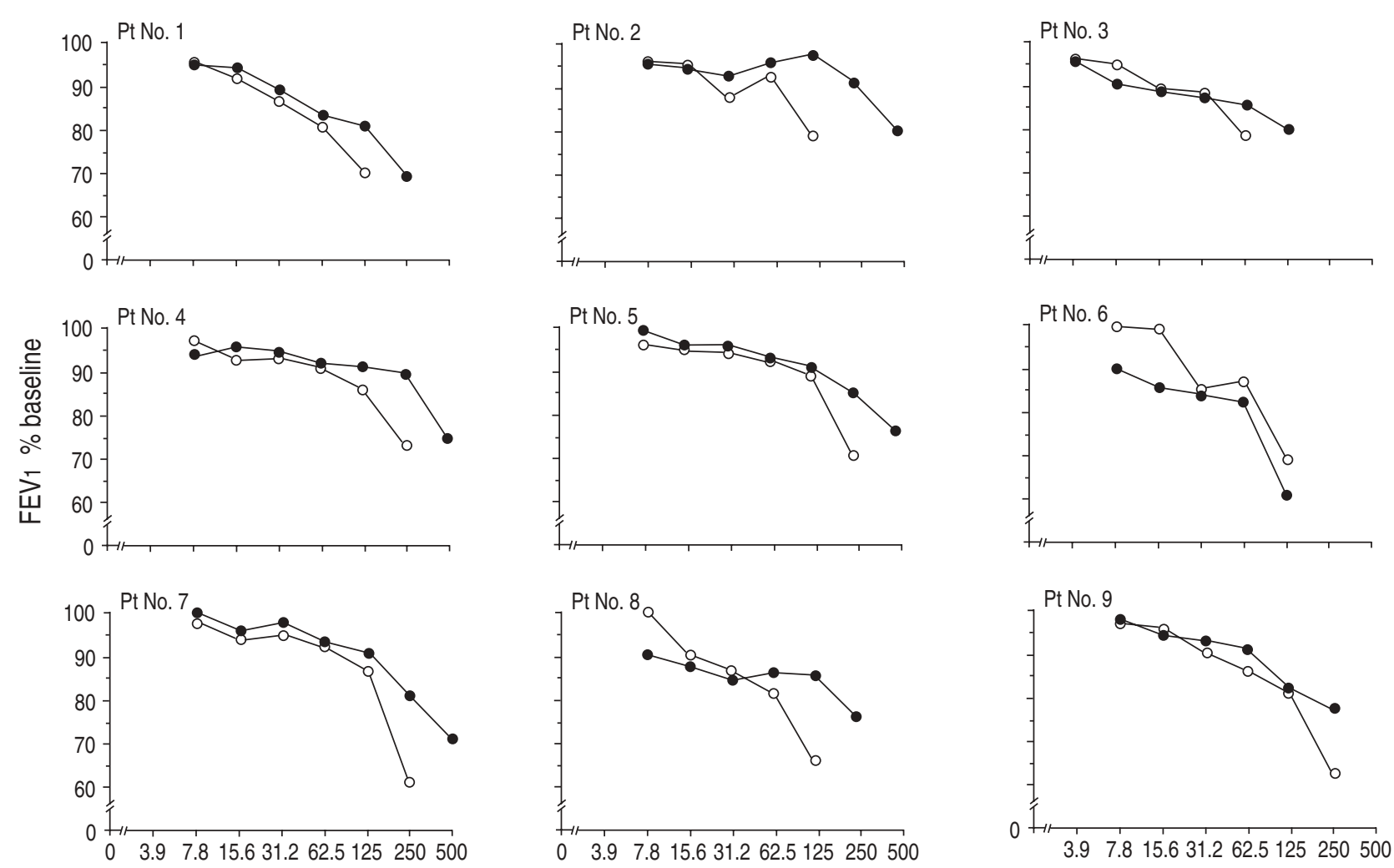

Cumulative concentration of NKA $\mu \mathrm{g} \cdot \mathrm{mL}^{-1}$

Fig. 1. - Effect of placebo ( $->$ ) and L-ASA ( $-\longrightarrow$ ) on the concentration-related falls in FEV1 produced by inhaled NKA in nine subjects with asthma. L-ASA: lysine acetylsalicylate; FEV1: forced expiratory volume in one second; NKA: neurokinin A; Pt: patient.
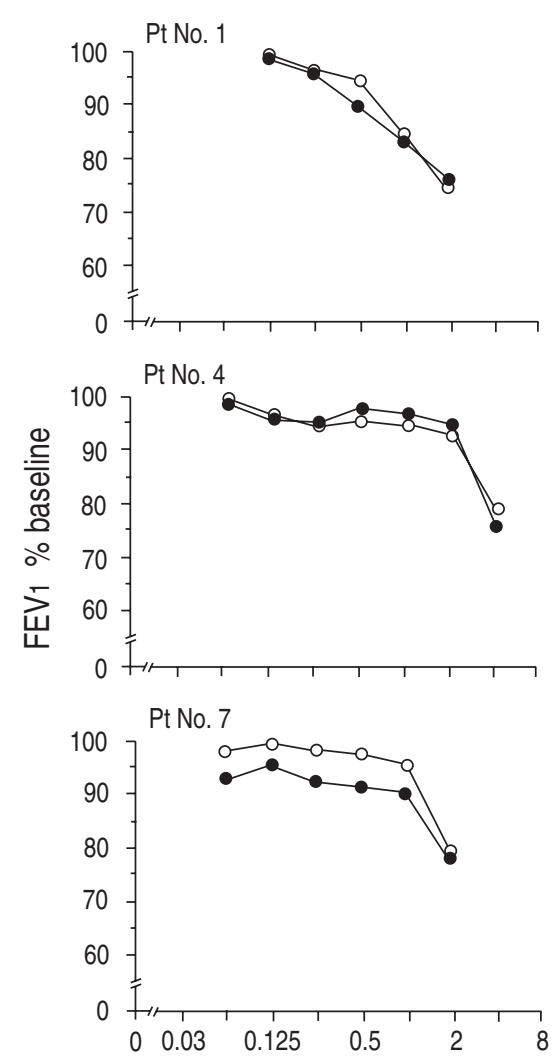
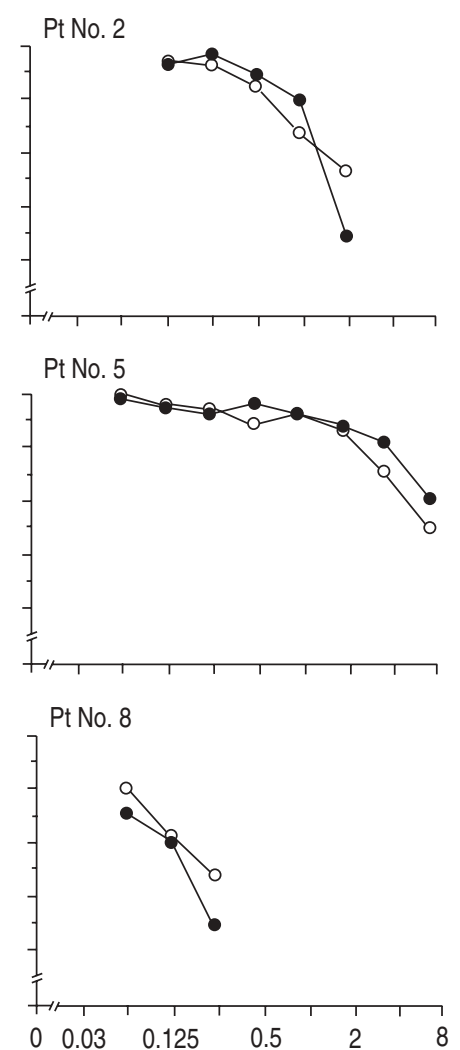
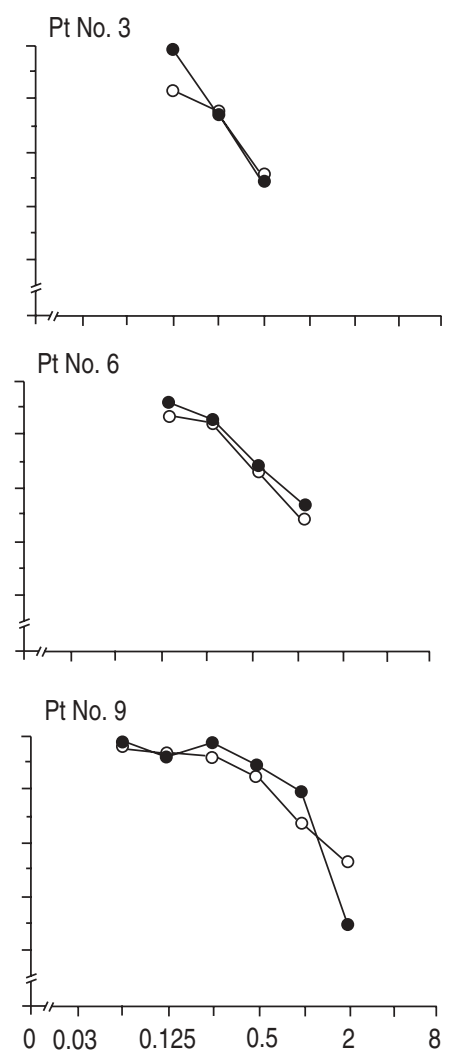

Cumulative concentration of methacholiine $\mathrm{mg} \cdot \mathrm{mL}^{-1}$

Fig. 2. - Effect of placebo ( $-\bigcirc-$ ) and L-ASA ( $\_-(-)$) on the concentration-related falls in FEV1 produced by inhaled methacholine in nine subjects with asthma. For abbreviations seee legend to figure 1. 
(PC20 methacholine $<4 \mu \mathrm{g} \cdot \mathrm{mL}^{-1}$ ). Thus, we may speculate that in these subjects with grossly inflamed airways aspirin exposure may elicit bronchoconstriction regardless of their state of tolerance/intolerance to this drug. It is widely acknowledged that historical evidence of aspirin tolerance is inadequate in excluding aspirin sensitivity. Thus, there is a possibility that the asthmatics studied may have inherent aspirin intolerance. However, it is well-known that only a small proportion of subjects with asthma are intolerant to aspirin [25], and it would appear highly unlikely to find that 8 out of 9 unselected patients have this condition! Moreover, the inhalation of L-ASA in aspirin-sensitive asthmatics is followed by bronchoconstriction 20-120 min after challenge, with gradual recover to within $5 \%$ of baseline by $180 \mathrm{~min}$ [26]. This is in contrast with the time-course of the bronchoconstriction induced by inhaled L-ASA obtained in this study. Maximum decrease in pulmonary function was reached 1 min after challenge, gradually resolving over $20 \mathrm{~min}$.

That cyclooxygenase blockade has a specific effect on airway responsiveness to NKA is supported by the lack of change in methacholine responsiveness after inhaled L-ASA. This is in agreement with previous data with cyclooxygenase blockers by our group [19, 20], and other authors $[27,28]$, which have repeatedly failed to show an effect on methacholine-induced bronchoconstriction.

In providing protection against a variety of different bronchoconstrictor stimuli, such as fog [17], adenosine [20] and histamine [19], the inhibitory effects of L-ASA may involve mechanisms common to all these stimuli. Thus, it is likely that the protective effect of inhaled aspirin in these experimental conditions may be ascribed to cyclooxygenase blockade. These observations, together with the results of the present study and the notion that aspirin's mode of action is through inhibition of the cyclooxygenase pathway, provide some evidence for a contribution of contractile prostaglandins to the neuropeptide response in human asthma. Indeed there is evidence in vitro that part of the biological effects of exogenously applied neuropeptides may result from the local release of bioactive prostaglandins [14-16]. However, the present study has shown only a small decrease in airway responsiveness to NKA after administration of L-ASA. Although the small protective effect of L-ASA on NKAinduced bronchoconstriction may be due to the fact that local concentrations of exogenous NKA were too low to maximally activate airway mast cells, this finding is in line with previous observations by $\mathrm{CHURCH}$ et al. [29] that neuropeptides are poor activators of the oxidative pathway for prostaglandins in human mast cells.

The inhibitory action of inhaled L-ASA in the airways in the absence of bronchodilatation is likely to be due to a suppressive action on the local production of prostaglandins with functional effects, but the contribution of alternative mechanisms in NKA-induced bronchoconstriction must be considered. A possibility is that endogenous prostaglandins may potentiate the constrictor response to NKA in the airways and that drugs such as aspirin might alter this interaction. NKA given by inhalation does not appear to stimulate the release of histamine [24], but it may activate cholinergic [30] and noncholinergic nerves $[10,13]$. Prostaglandins are neuromodulators, stimulate airway sensory nerves [31], and augment neuro-transmission in efferent airway nerves [32]. Therefore, endogenous prostaglandins may potentiate the response of asthmatic airway nerves to inhaled NKA, and only part of the effects of NKA may result from the direct release of contractile prostaglandins. On the other hand, cyclooxygenase products activate tachykinin release from capsaicin-sensitive afferents in guinea-pig airways [33], and stimulate both pulmonary and bronchial $\mathrm{C}$ fibres in dogs [34]. Other possible explanations for the L-ASA reduction in NKA responsiveness in asthma may include down regulation of NK receptors, and modulation of postreceptor events coupled to NKA-mediated contraction of smooth muscle.

In conclusion, our results demonstrate that inhaled LASA produces some protection against NKA-provoked bronchoconstriction in asthmatic subjects. Whilst suggesting that prostanoids mediate a component of the bronchoconstriction produced by NKA in asthma, their contribution to the overall response is likely to be small. Thus, although the exact role and the mode of action of NKA in human airways remains unclear, one important mechanism may be dependent on the direct action exerted on specific receptors of bronchial smooth muscle [35-37].

The ability of inhaled L-ASA to contribute to the protection of asthmatic airways against a wide variety of bronchoconstrictor stimuli, together with the notion that asthma is an inflammatory disease of the bronchial tree [38], suggest that cyclooxygenase blockers may be viewed as possible prophylactic drugs for the treatment of asthma. Thus, although analgesic and antiaggregant properties dominate its use in medicine, aspirin may also play a role in limiting the allergic inflammatory events associated with asthma. More work is needed to explore the full potential of this class of drug on constrictor stimuli in asthma and whether this has any relevance to a possible therapeutic effect in this disease.

\section{References}

1. Barnes PJ, Baraniuk JN, Belvisi MG. Neuropeptides in the respiratory tract. Am Rev Respir Dis 1991; 144: $1187-1198$

2. Lundberg JM, Hokfelt T, Martling C-R, Saria A, Cuello C. Substance $\mathrm{P}$ immunoreactive sensory nerves in the lower respiratory tract of various mammals including man. Cell Tissue Res 1984; 235: 251-261.

3. Hislop AA, Wharton J, Allen KM, Polak JM, Haworth SG. Immunohistochemical localization of peptide-containing nerves in human airways: age-related changes. Am J Respir Cell Mol Biol 1990; 3: 191-198.

4. Baraniuk JN, Lundgren JS, Okayama M, et al. Substance $\mathrm{P}$ and neurokinin A in human nasal mucosa. Am J Respir Cell Mol Biol 1991; 4: 228-236.

5. Ollerenshaw SL, Jarvis JD, Sullivan CE, Woolcock AJ. Substance P immunoreactive nerves in airways from asthmatics and nonasthmatics. Eur Respir J 1991; 4: 673-682.

6. Nieber K, Baumgarten CR, Rathsack R, Furkert J, Oehme $\mathrm{P}$, Kunkel G. Substance $\mathrm{P}$ and $\beta$-endorphin-like immunoreactivity in lavage fluid of subjects with and without allergic asthma. J Allergy Clin Immunol 1992; 60: 646652.

7. Tomaki M, Ichinose M, Miura M, et al. Elevated substance $\mathrm{P}$ content in induced sputum from patients with asthma and patients with chronic bronchitis. Am J Respir Crit Care Med 1995; 151: 613-617. 
8. Joos G, Pauwels R, Van der Straeten M. The effect of inhaled substance $\mathrm{P}$ and neurokinin $\mathrm{A}$ on the airways of normal and asthmatic subjects. Thorax 1987; 42: 779-783.

9. Crimi N, Palermo F, Oliveri R, et al. Effect of nedocromil on bronchospasm induced by inhalation of substance $\mathrm{P}$ in asthmatic subjects. Clin Allergy 1988; 18: 375-382.

10. Crimi N, Palermo F, Oliveri R, Palermo B, Polosa R, Mistretta A. Protection of nedocromil sodium on bronchoconstriction induced by inhaled neurokinin $\mathrm{A}$ in asthmatic patients. Clin Exp Allergy 1992; 22: 75-81.

11. Cheung D, Bel EH, den Hartigh J, Dijkman JH, Sterk PJ. The effect of an inhaled NEP inhibitor, thiorphan, on airway responses to neurokinin A in normal humans in vivo. Am Rev Respir Dis 1992; 145: 1275-1280.

12. Cheung D, Timmers MC, Zwinderman AH, den Hartigh J, Dijkman JH, Sterk PJ. NEP activity and airway hyperresponsiveness to neurokinin A in asthmatic subjects in vivo. Am Rev Respir Dis 1993; 148: 1467-1473.

13. Joos G, Pauwels R, Van der Straeten M. The effect of nedocromil sodium on the bronchoconstrictor effect of neurokinin A in subjects with asthma. J Allergy Clin Immunol 1989; 83: 663-668.

14. Russell JA. Substance P elicits thromboxane-induced contraction of canine pulmonary veins. Pulm Pharmacol 1988; 1: 153-159.

15. Selig WM, Burhop KE, Garcia JGN, Malik AB. Substance $\mathrm{P}$ induced pulmonary vasoreactivity in isolated perfused guinea pig lung. Circul Res 1988; 62: 196-203.

16. Frossard N, Rhoden KJ, Barnes PJ. Influence of epithelium on guinea pig airway responses to tachykinins: role of endopeptidase and cyclooxygenase. J Pharmacol Exp Ther 1989; 248: 292-298.

17. Bianco S, Vaghi A, Pieroni MG, Robuschi M, Refini RM, Sestini P. Protective activity of inhaled nonsteroidal anti-inflammatory drugs on bronchial responsiveness to ultrasonically nebulized water. J Allergy Clin Immunol 1992; 90: 833-839.

18. Bianco S, Vaghi A, Pieroni MG, et al. Potentiation of the antireactive, antiasthmatic effect of inhaled furosemide by inhaled lysine acetylsalicylate. Allergy 1993; 48: 570-575.

19. Crimi N, Polosa R, Prosperini G, et al. Effect of inhaled lysine acetylsalicylate (L-ASA) on the airways responsiveness to histamine in asthmatic subjects. Am J Respir Crit Care Med 1994; 149: A1055.

20. Crimi N, Polosa R, Magrì S, et al. Inhaled lysine acetylsalicylate (L-ASA) attenuates the bronchoconstrictor response to adenosine 5'-monophosphate (AMP) in asthmatic subjects. Eur Respir J 1995; 8: 905-912.

21. Lewis RA. Therapeutic aerosols. In: Bonsignore GC, Bonsignore C, eds. Drugs and the lung. London, Plenum, 1984; pp. 63-86.

22. Chai H, Farr RS, Froehlich LA, et al. Standardization of bronchial inhalation challenge procedures. J Allergy Clin Immunol 1975; 56: 323-327.

23. Altman DG, Bland JH. Statistical methods for assessing agreement between two methods of clinical measurement. Lancet 1986, 8: 307-310.
24. Crimi N, Oliveri R, Polosa R, Palermo F, Mistretta A. The effect of oral terfenadine on neurokinin A-induced bronchoconstriction. J Allergy Clin Immunol 1993; 91: 1096-1098.

25. Szczeklik A. The cyclooxygenase theory of aspirininduced asthma. Eur Respir J 1990; 3: 588-593.

26. Phillips GD, Foord R, Holgate ST. Inhaled lysine-aspirin as a bronchoprovocation procedure in aspirin-sensitive asthma: its repeatability, absence of a late phase reaction, and the role of histamine. J Allergy Clin Immunol 1989; 84: 232-241.

27. Fish JE, Ankin MG, Adkinson NF, Peterman VI. Indomethacin modification of the immediate-type immunologic airway responses in allergic asthmatic and non-asthmatic subjects. Am Rev Respir Dis 1981; 123: 609-614.

28. Sterk PJ, Daniel EE, Zamel N, Hargreave FE. Limited maximal airway narrowing in nonasthmatic subjects: role of neural control and prostaglandin release. Am Rev Respir Dis 1985; 132: 865-870.

29. Church MK, Benyon RC, Rees PH, et al. Functional heterogeneity of human mast cells. In: Galli SJ, Austen $\mathrm{KF}$, eds. Mast Cell and Basophil Differentiation and Function in Health and Disease. New York, Raven Press, 1989; pp. 161-170.

30. Joos GF, Pauwels R, Van der Straeten ME. The effect of oxitropium bromide on neurokinin A-induced bronchoconstriction in asthmatics. Pulm Pharmacol 1988; 1 : 41-45.

31. Coleridge HM, Coleridge JC, Roberts AM. Rapid shallow breathing evoked by selective stimulation of airway C fibers in dogs. J Physiol (Lond) 1983; 340: 415-433.

32. Walters EH, O'Byrne PM, Fabbri LM, Graf PD, Holtzmann MJ, Nadel JA. Control of neurotransmission by prostaglandins in canine trachealis smooth muscle. $J$ Appl Physiol: Respirat Environ Exercise Physiol 1984; 57: 129-134.

33. Mapp CE, Fabbri LM, Boniotti A, Maggi CA. Prostacyclin activates tachykinin release from capsaicin-sensitive afferents in guinea-pig bronchi through a ruthenium red sensitive pathway. Br J Pharmacol 1991; 104: 49-52.

34. Roberts AM, Schultz HD, Green JF, et al. Reflex tracheal contraction evoked in dogs by bronchodilator prostaglandins $\mathrm{E}_{2}$ and $\mathrm{I}_{2}$. J Appl Physiol 1985; 58: 1823-1828.

35. Naline E, Devillier P, Drapeau G, et al. Characterization of neurokinin effects and receptor selectivity in human isolated bronchi. Am Rev Respir Dis 1989; 140: 679-686.

36. Morimoto H, Murai M, Maeda Y, et al. FK-224: a novel cyclopeptide substance P antagonist with NK1 and NK2 receptor selectivity. J Pharmacol Exp Ther 1992; 262: 398-402.

37. Murai M, Morimoto H, Maeda Y, et al. Effects of FK224, a novel NK1 and NK2 receptor antagonist, on airway constriction and airway edema induced by neurokinins and sensory nerve stimulation in guinea-pigs. J Pharmacol Exp Ther 1992; 262: 403-408.

38. Djukanovic R, Roche WR, Wilson JW, et al. Mucosal inflammation in asthma. State of the art. Am Rev Respir Dis 1990; 142: 434-457. 